\title{
An approach on the in vitro maintenance of sugarcane with views for conservation and monitoring of plant nuclear DNA contents via flow cytometry
}

\author{
Gabriela Ferreira Nogueira • Leila Aparecida Salles Pio • \\ Moacir Pasqual • Adriane Amaral • \\ Jonny Everson Scherwinski-Pereira
}

Received: 8 May 2014 / Accepted: 25 November 2014 / Published online: 9 December 2014 / Editor: John Forster

(C) The Society for In Vitro Biology 2014

\begin{abstract}
In vitro conservation techniques can be utilized for germplasm maintenance. However, few reports on the in vitro conservation of sugarcane species are present in the literature. The objective of this study was to subject sugarcane plants to in vitro under minimal growth conditions and to evaluate the survival, regeneration, and the monitoring of nuclear DNA content levels of the plants. Shoots from 10 sugarcane varieties (Saccharum spp.) were introduced into two media: MC1, consisting of half-strength Murashige and Skoog (MS) salts and 3\% sorbitol, or MC2, similar to the first formulation, but additionally supplemented with $3.8 \mu \mathrm{M}$ abscisic acid (ABA). The shoots were maintained for up to $12 \mathrm{mo}$ at $18^{\circ} \mathrm{C}$ in the presence of light. At the end of the period, the explants were inoculated onto multiplication medium containing $0.9 \mu \mathrm{M} 6$ benzylaminopurine (BAP) and $0.47 \mu \mathrm{M}$ kinetin (Kin) for growth recovery. Flow cytometry analysis of shoots was verified at every 6 mo of storage. As a result, we found distinct behaviors of the varieties studied over the storage time, but in general, $\mathrm{MC} 1$ provided the greatest explant survival rates, with an average of approximately $80 \%$ cultures being able to recover. Once in the recovery media, the explant regrowth was fast, and the ability to multiply shoots was reestablished from
\end{abstract}

G. F. Nogueira

Capes/Embrapa Project, Embrapa Genetic Resources and

Biotechnology, Brasília, DF, Brazil

L. A. S. Pio · M. Pasqual

Federal University of Lavras, Lavras, MG 37200-000, Brazil

A. Amaral

Embrapa Coastal Tablelands, Av. Beira Mar, 3250, Aracaju, SE 49025-040, Brazil

J. E. Scherwinski-Pereira $(\square)$

Embrapa Genetic Resources and Biotechnology, Av. W5 Norte

(final), PqEB, Brasília, DF 70770-917, Brazil

e-mail: jonny.pereira@embrapa.br the second 30-d subculture. However, by flow cytometry analysis, we observed a decrease in the estimated relative amount of DNA at 12 mo storage for most varieties examined, which was not observed when the monitoring was done at 6 mo. From these results, we conclude that sugarcane plants survived the minimal growth condition; however, maintaining the genotypes for extended periods in vitro may lead to variations in the estimated amount of nuclear DNA and, thus, be at risk of somaclonal variation.

Keywords Saccharum spp. · Minimal growth · Flow cytometry $\cdot$ DNA content $\cdot$ Germplasm conservation

\section{Introduction}

The development of biofuels from renewable resources is essential for the sustainability of the world economy, environmental preservation, and mitigation of the effects of $\mathrm{CO}_{2}$ emissions (Matsuoka et al. 2009) considered mainly responsible for the greenhouse effect and global climate change (Cheng and Timilsina 2011). Ethanol is produced from the fermentation of sugars such as sucrose and starch (Waclawovsky et al. 2010). In the USA, ethanol production almost entirely originates from cornstarch. In Brazil, the juice from sugarcane is the preferred carbon source, accounting for about $80 \%$ of bioethanol production (Sainz 2009).

To meet the increasing demand of the domestic market, research has been increasingly focused on developing plant varieties with high biomass production and better responsiveness to different cultivation environments in Brazil, aiming at higher bioenergy production (Waclawovsky et al. 2010; Dos Santos et al. 2012). Given the genetic variability of sugarcane included in the traditional, improved, and native species and varieties, it is necessary to preserve the gene pool with view to 
further genetic improvement. However, being a species that propagates vegetatively, germplasm preservation presents a disadvantage since the most practical conservation form is seeds, which are not a viable alternative (Martín et al. 2013).

Thus far, the conservation of sugarcane germplasm is supplied from gene bank collections maintained in the field (Roach 1995). However, with improvements in plant tissue culture techniques, in vitro conservation, in particular the minimal growth method, has become a useful alternative for the conservation of genetic resources of Saccharum spp. (Engelmann 2011; Martín et al. 2013). The minimal growth method has been successfully used for conservation over the short- and medium-term especially meristems and/or shoot apices of many species and consists of reducing growth and increasing the intervals between subcultures, without significantly affecting the explant viability (Engelmann 2011). This reduction in metabolic activity is generally achieved by modification of the physical environment and/or the composition of the culture medium (Scherwinski-Pereira and Costa 2010). The approaches widely used involve the reduction of cultivation temperature and addition of osmotically active compounds in the culture medium, such as sucrose, sorbitol, or mannitol (Marino et al. 2010). Often, growth inhibitors, such as abscisic acid (ABA), are also used (Rai et al. 2011). For sugarcane, the reduction of salts and vitamins was tested by Taylor and Dukic (1993), osmotic stress was evaluated by Sarwar and Siddiqui (2004), and the combination of factors by Lemos et al. (2002). In these studies, although survival rates varied, none of them utilized genetic or cytological studies to evaluate the genetic stability of plants maintained in vitro.

Mainly for diploid plant species, molecular markers, such as Amplified Fragment Length Polymorphism (AFLP), Simple Sequence Repeat (SSR), and Inter-Simple Sequence Repeat (ISSR) have been successfully used for screening genetic stability of tissue culture plants (Huang et al. 2009; Neelakandan and Wang 2012; Singh et al. 2013). However, for species with a complex level of polyploidy, such as sugarcane, these tools are unsuitable and results are difficult to interpret (Comai 2005; Park et al. 2012; Garcia et al. 2013). On the other hand, cytological investigation of sugarcane using microscopic techniques is often difficult and complex due to the large number and small size of their chromosomes and existence of various cytotypes (Edmé et al. 2005; Suganya et al. 2012). In this sense, the flow cytometry technique has gained special attention since it allows the estimation of the relative amount of nuclear DNA of plant cells quickly and with high precision (Jin et al. 2008; Bairu et al. 2011; Smulders and de Klerk 2011). Overall, cytometry is able to distinguish between plants from the different cultivation techniques in vitro and has been widely applied in research involving many economically important species such as Vitis vinifera (Yang et al. 2008; Prado et al. 2010), Gossypium hirsutum (Jin et al. 2008), Musa spp. (Msogoya et al. 2011), Passiflora spp. (Silva et al. 2011), Elaeis guineensis (Madon et al. 2012), Coffea arabica (Clarindo et al. 2012), Prunus cerasus (Vujović et al. 2012), and Musa acuminata (Escobedo-GraciaMedrano et al. 2014). For sugarcane, to the best of our knowledge, no flow cytometry analysis of plants regenerated and/or maintained in vitro is available in the literature.

This work aimed to initially evaluate the survival and growth recovery of 10 Brazilian sugarcane varieties maintained under different minimal growth conditions in vitro. Additionally, the cultures were periodically assessed by flow cytometry to determine the nuclear DNA content levels of materials during and after the adopted procedures.

\section{Material and Methods}

To determine the best conditions for sugarcane germplasm conservation, a suitable culture medium was initially determined. For this experiment, initial shoots from two varieties of Saccharum spp. (IAC862210 and RB855453) were established and multiplied in vitro for up to three subcultures, according to the protocol of Nogueira et al. (2013).

Determination of the culture medium to induce slow growth of the sugarcane genotypes. The culture medium that induced slow growth in sugarcane varieties was determined from three experiments. In the first experiment, we evaluated the Murashige and Skoog (MS) basic culture medium (Murashige and Skoog 1962) prepared under different salt concentrations: full-, $3 / 4-$, and $1 / 2$-strength MS, with the original concentration of vitamins being maintained. In the second experiment, the effects of the addition of carbohydrates sucrose, sorbitol, or mannitol in MS culture medium in concentrations of $1 \%, 2 \%$, or $3 \%(w / v)$ were evaluated. Finally, in a third experiment, the basic MS medium was supplemented with $0,3.8,7.6,15.2$, or $30.4 \mu \mathrm{M}$ abscisic acid (ABA). In this experiment, ABA was sterilized by filtration $(0.22 \mu \mathrm{m}$ Millipore, Tullagreen, Ireland) before being added to autoclaved culture medium.

In all three initial experiments, the culture media were adjusted to $\mathrm{pH} 5.8 \pm 0.1$ before autoclaving at $121^{\circ} \mathrm{C}$ for $20 \mathrm{~min}$ at $1.5 \mathrm{~atm}$ pressure and solidified with $2.3 \mathrm{~g} \mathrm{~L}^{-1}$ Phytagel (Sigma, St. Louis, MO). The initial shoot size was standardized to $\sim 1.5 \mathrm{~cm}$, and inoculated media were maintained in a growth room at $25 \pm 2^{\circ} \mathrm{C}, 12$-h photoperiod, and $30 \mu \mathrm{mol} \mathrm{m} \mathrm{s}^{-2} \mathrm{~s}^{-1}$ irradiation. As a repetition, we used at least 10 test tubes $(25 \times 150 \mathrm{~mm})$ with $10 \mathrm{~mL}$ of medium per treatment. In this first stage, the assessment of survival, formation, and height of shoots was conducted after 6 mo of storage. Once obtained, the data were evaluated, and the best two conservation treatments were used for the short-medium term genotype conservation experiment, as described below. 
Short- and medium-term conservation of plant material and determination of genomic instability. Shoot apices of 10 Brazilian sugarcane (Saccharum spp.) varieties (SP784764, SP716949, SP854594, SP701143, RB845210, RB99395, RB83160, RB863129, VAT90-212, and VAT90-186) were collected in the Germplasm Bank of Embrapa Coastal Tablelands in Rio Largo, Alagoas, Brazil and sent to the Tissue Culture Laboratory II of the Embrapa Genetic Resources and Biotechnology, located in Brasília, Distrito Federal, Brazil, where the experiments were conducted.

Initially, apices were surface sterilized with $70 \%(v / v)$ ethanol for $1 \mathrm{~min}$, sodium hypochlorite ( $\mathrm{NaClO} ; 2.5 \%$ active chlorine) for $20 \mathrm{~min}$ and washed three times in autoclaved distilled water. After asepsis, the innermost portion and chlorophyllated tissues were transversely sectioned into explants of approximately $3 \mathrm{~mm}$, which were inoculated in a culture medium containing MS salts and vitamins supplemented with 3\% sucrose, $26.9 \mu \mathrm{M}$ naphthalene acetic acid (NAA), $2.33 \mu \mathrm{M}$ kinetin (Kin), and solidified with $2.3 \mathrm{~g} \mathrm{~L}^{-1}$ Phytagel ${ }^{\mathrm{TM}}$, according to the protocol established by Gill et al. (2006).

After $40 \mathrm{~d}$ of cultivation under light conditions, the regenerated shoots were transferred to $250-\mathrm{mL}$ glass vials containing $30 \mathrm{~mL}$ of MS medium with added $3 \%$ sucrose, $0.47 \mu \mathrm{M}$ Kin, $0.9 \mu \mathrm{M}$ 6-benzylaminopurine (BAP), and solidified with $2.3 \mathrm{~g} \mathrm{~L}^{-1}$ Phytagel where they were multiplied by two subcultures of $30 \mathrm{~d}$ each in order to obtain the required number of shoots for the experiments.

Induction of minimal growth. For in vitro storage and verification of sugarcane shoot tolerance to minimal growth conditions, two formulations of the culture medium were tested. MC1 consisted of $1 / 2 \mathrm{MS}$ salts plus 3\% sorbitol and solidified with $2.3 \mathrm{~g} \mathrm{~L}^{-1}$ Phytagel. The second medium, called MC2, was similar to the first but additionally supplemented with $3.8 \mu \mathrm{M}$ abscisic acid (ABA). The $\mathrm{pH}$ of both culture media was adjusted to $5.8 \pm 0.1$ before autoclaving at $121^{\circ} \mathrm{C}$ at $1.5 \mathrm{~atm}$ for $20 \mathrm{~min}$. After sterilization, ABA was added to the MC2 culture medium by microfiltration using a filter $(0.22 \mu \mathrm{m})$.

After inoculation in a laminar flow hood, the shoots were stored for up to $12 \mathrm{mo}$ in an incubator chamber (model EL$202 / 3$, Eletrolab Ltd., SP, Brazil) at a temperature of $18^{\circ} \mathrm{C}, 12-$ $\mathrm{h}$ photoperiod and irradiation of $30 \mu \mathrm{mol} \mathrm{m} \mathrm{m}^{-2} \mathrm{~s}^{-1}$. During the storage period, no renewal of the culture medium was carried out.

As a repetition, we used 10 test tubes per variety within each treatment: presence and absence of ABA. Each test tube was filled with $10 \mathrm{~mL}$ of culture medium and received a shoot with an initial length of $1.5 \mathrm{~cm}$.

Evaluation of survival was performed every 3 mo of storage by visual evaluations, while the length and the number of shoots and roots formed were evaluated only at the end of the experiment. After collecting the data regarding survival, they were analyzed following a split-plot scheme and compared by statistical regression by the Sisvar ${ }^{\circledR}$ program (Ferreira 2011) The other variables were evaluated according to a $2 \times 10$ factorial design (10 varieties $\times$ two culture media). Data in percentage were previously transformed by arcsine aiming to meet the assumptions necessary for the analysis. The comparison of means was made by the Scott-Knott test at 5\% of probability.

Growth recovery. At the end of 12 mo of in vitro storage, the shoots were removed from their respective minimal growth media and introduced into multiplication medium for growth recovery. The multiplication medium consisted of MS salts and vitamins supplemented with $3 \%$ sucrose and $0.47 \mu \mathrm{M}$ Kin in combination with $0.9 \mu \mathrm{M}$ BAP and solidified with $2.3 \mathrm{~g} \mathrm{~L}^{-1}$ Phytagel. After the transfer, the explants were kept in a growth room in the presence of light at a temperature of $25 \pm 2^{\circ} \mathrm{C}$, 16-h photoperiod, and $50 \mu \mathrm{mol} \mathrm{m}{ }^{-2} \mathrm{~s}^{-1}$ irradiation.

The survival, multiplication rate and the length of the longest shoot were evaluated after $30 \mathrm{~d}$ of cultivation in this medium. The shoots were then transferred again to the same medium in order to verify their behavior in a second consecutive subculture. The experimental design was completely randomized, forming a $10 \times 2$ factorial design for varieties and culture media source (MC1 or MC2). The data were then analyzed by the Sisvar statistical program, and means were compared by the Scott-Knott test at 5\% probability.

Genomic stability analysis by flow cytometry. Samples collected at 0 (control), 6, and 12 mo of in vitro storage were conducted in culture medium to the Tissue Culture Laboratory of the Agriculture Department, Federal University of Lavras-UFLA for the determination of genomic stability through flow cytometry.

Approximately 20-30 mg of young leaves from shoots and from the external reference standard (Lycopersicum esculentum L.) was used for sample preparation. The tissues were ground in Petri dishes $(10 \times 90 \mathrm{~mm})$ containing $1 \mathrm{~mL}$ of cold extraction buffer to release the nuclei (Dolezel et al. 1994). The buffer used for the analyses was Marie (Marie and Brown 1993), composed of $50 \mathrm{mM}$ glucose, $15 \mathrm{mM}$ $\mathrm{NaCl}, 15 \mathrm{mM} \mathrm{KCl}, 5 \mathrm{mM} \mathrm{Na}{ }_{2}$ EDTA, $50 \mathrm{mM}$ sodium citrate, $0.5 \%$ Tween 20, $50 \mathrm{mM}$ HEPES $(\mathrm{pH} 7.2)$, and 1\% $(\mathrm{m} / \mathrm{v})$ polyvinylpyrrolidone-10 (PVP-10).

After the extraction process, the nuclei suspension was aspirated with the aid of a Pasteur pipette and filtered through a $50-\mu \mathrm{m}$ mesh. Nuclei were stained by addition of $25 \mu \mathrm{L}$ of $1 \mathrm{mg} \mathrm{mL}{ }^{-1}$ propidium iodide (Sigma, St. Louis, MO). The nuclear DNA content (pg) of the plants was estimated using the following formula: DNA of the sample $=(\mathrm{G} 1$ of the sample/G1 of the standard) $\times$ standard DNA. 
The analyses were conducted in a FacsCalibur cytometer (BD, Bioscienses, San Jose, CA) and histograms statistically analyzed in WinMDI 2.8 software. The experimental design was completely randomized and for each time analyzed, we used four plants per variety and two readings in the cytometer. The DNA contents (pg) obtained were subjected to analysis of variance, and means were compared by the Tukey test at $5 \%$ probability in the Sisvar statistical program.

Rooting and acclimatization. After growth recovery, the sugarcane plants were separated and transferred to culture medium containing MS salts and vitamins plus 3\% sucrose and $2.3 \mathrm{~g} \mathrm{~L}^{-1}$ Phytagel for rooting. The $\mathrm{pH}$ was adjusted to $5.8 \pm$ 0.1 before autoclaving at $121^{\circ} \mathrm{C}$ at $1.5 \mathrm{~atm}$ for $20 \mathrm{~min}$. After inoculation, the shoots were kept in a growth room under light conditions, temperature of $25 \pm 2^{\circ} \mathrm{C}, 16$-h photoperiod, and irradiance of $50 \mu \mathrm{mol} \mathrm{m}^{-2} \mathrm{~s}^{-1}$ where they remained for $40 \mathrm{~d}$.

Soon after, and while still in the growth room, we initiated the plant pre-acclimatization process. First, we removed the plastic wrap used to seal the test tubes, and $72 \mathrm{~h}$ later, the covers were also removed. After $48 \mathrm{~h}$ without any type of sealing, the shoots were washed in running water to remove residue from the culture medium and taken to the greenhouse where they were transplanted in trays of 60 cells containing substrate (Bioplant, Nova Ponte, MG, Brazil) and sand at a 1:1 $(v / v)$ proportion. The survival percentage was assessed after $21 \mathrm{~d}$ of acclimatization in the greenhouse.

\section{Result and Discussion}

Determination of the culture medium to induce the slow growth of sugarcane varieties. To determine the optimal culture medium for the slow growth of sugarcane, we compared the mean survival rate, height, and new shoot production of plantlets subjected to different MS medium formulations regarding salt concentrations, types, and concentrations of carbohydrates and use of ABA (Table 1). In relation to the salt (MS) concentrations, a high production of secondary shoots (10 per explant) and an average shoot growth of $8.2 \mathrm{~cm}$ were observed in the three media tested. However, the survival rate was higher when they were kept in medium containing less nutrient salts ( $1 / 2 \mathrm{MS})$, with a mean of $68 \%$ compared to $12.5 \%$ for full-strength MS.

The type of carbohydrate used in the culture medium, as well as its concentration was a determining factor in reducing the growth of plants maintained in vitro. Sucrose yielded taller and a higher number of secondary shoots than media with sorbitol or mannitol, which consequently undermined shoot survival over a longer period of cultivation, possibly by increasing the adsorption and/or depletion of nutrients of the culture medium (Table 1). Mannitol, as a carbon source, presented the highest shoot mortality rate $(90-100 \%)$ at all concentrations evaluated. The use of $3 \%$ sorbitol in the culture medium proved to be the best for reducing carbohydrate metabolism and especially for maintaining shoot survival, reaching an average of $100 \%$ at the end of the experiment.

In general, the addition of abscisic acid (ABA) significantly reduced the growth of the sugarcane plants $(2.7 \mathrm{~cm})$ and suppressed the production of new shoots ( 2.4 per explant). However, we found that $30.4-\mu \mathrm{M}$ ABA was detrimental to shoot survival since only $10 \%$ of plants survived (Table 1 ). Based on these results, the most appropriate culture conditions for the conservation of sugarcane varieties by minimum growth method required half-strength MS medium, with 3\% added sorbitol.

Induction of minimal growth and recovery of growth. For the conservation of sugarcane, the modification of the culture medium and a reduction in cultivation temperature had a significant effect on in vitro plant growth and consequently the time required between subcultures. In general, culture medium devoid of ABA (MC1) provided the highest explant survival rates after 12 mo storage compared to the culture medium with ABA (MC2). However, we noted distinct behavior of the 10 varieties studied for the storage period (Fig. 1).

The SP784764 variety responded better to our conservation treatments, since at 12 mo of storage, 85 and $100 \%$ survival rates were recorded when the explants were cultured in the presence or absence of ABA, respectively. Varieties RB83160, RB863129, VAT90-186, and VAT90-212 showed a similar behavior with respect to comparative shoot survival percentages in response to the culture media used for the minimal growth (Fig. 1). In MC1, shoots remained viable for 12 mo without need for subculture. In the presence of $\mathrm{ABA}$, however, there was a decreasing linear trend in their survival rates, but it was more accentuated for RB863129.

Two sugarcane varieties (SP701143 and RB99395) were more sensitive to storage at the conditions in this study, since shoot survival decreased significantly during the first month of incubation, especially when stored in the presence of ABA. At the end of $12 \mathrm{mo}$, we observed a survival of only $10 \%$ of the shoots of the RB99395 variety in MC1 (-ABA) and no survival of the SP701143 variety in MC2 (+ABA). Varieties RB845210, SP854594, and SP716949 showed a decreasing trend in the shoot viability during storage in minimal growth medium. For RB845210, the maintenance of explants in MC2 for more than 3 mo was detrimental to their survival (Fig. 1). According to Naidu and Sreenath (1999), in vitro conservation protocols must reflect the maximum survival rate with a minimum number of subcultures. In the present work, most varieties in culture medium with $\mathrm{ABA}$ (MC2) had survival rates below $60 \%$, suggesting that including $\mathrm{ABA}$ was not optimal for the maintenance of sugarcane shoots. 
Table 1 Behavior of sugarcane plants in relation to survival, height and shoot number after 6 mo of maintenance in vitro under different culture medium formulations.

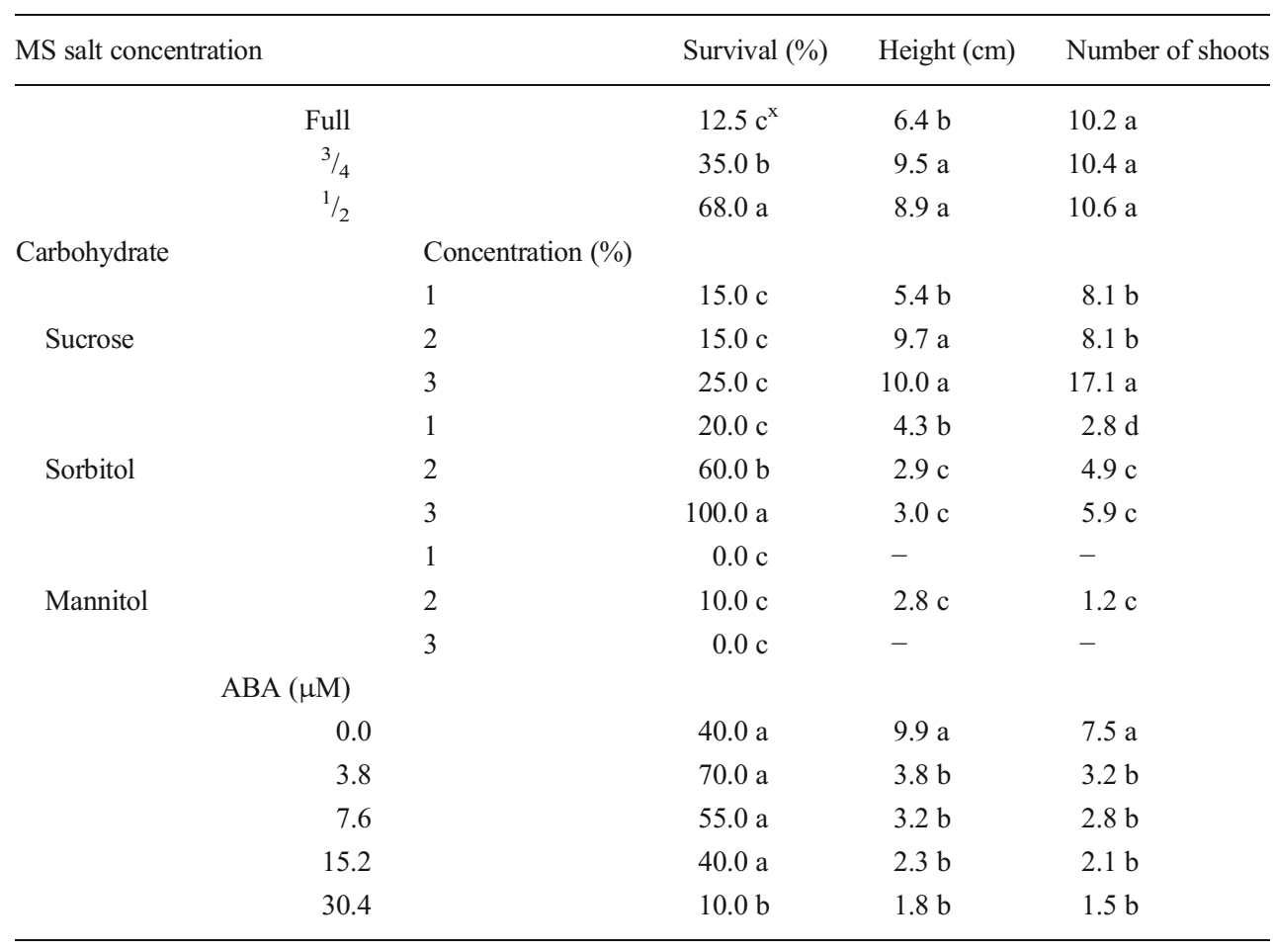

For this experiment, shoots from two varieties of Saccharum (IAC862210 and RB855453) were used, and the values presented refer to the overall mean observed

(-) Dead shoots

${ }^{\mathrm{x}}$ Means followed by the same letter in a column, within each treatment, belong to the same group and do not differ by the Scott-Knott test at 5\% probability techniques (Danso and Ford-Llyod 2008; Popova et al. 2009). However, the responses varied among various species.

In the present work, it was possible that the combination of the sugar alcohol (sorbitol) with the growth inhibitor (ABA) and the temperature reduced to $18^{\circ} \mathrm{C}$ resulted in excessive shoot growth restrictions for most of the sugarcane varieties studied. Unlike what was observed in the MC2 medium, satisfactory shoot survival levels $(\sim 80 \%)$ were observed in storage using $\mathrm{MC1}$, under the same conditions without ABA. This enabled explants to be maintained for 12 consecutive mo in vitro, without the need for culture medium renewal.

Given the conditions provided herein to the sugarcane genotypes, increased shoot growth was observed for shoots conserved in the absence of ABA (MC1; Table 2). In this medium, we observed the development of shoots with increased length and production of new leaves and shoots. However, during the 12-mo storage period, the growth ceased, and in some cases, older leaves became yellowish and necrotic (Table 2; Fig. 2).

The explants maintained in MC2 had higher growth restrictions since they practically maintained the initial size of the shoots $(1.5 \mathrm{~cm})$. In general, the shoot behavior in the MC2 medium was similar for all varieties, and no statistical differences were detected in the variables analyzed (Table 2).

The preservation of plant material in vitro depends on the genotype, the type of explant, culture medium composition, environmental conditions, and the storage period. In general, medium with low nutrient availability causes explants to reduce their growth rate. However, maintenance over long 


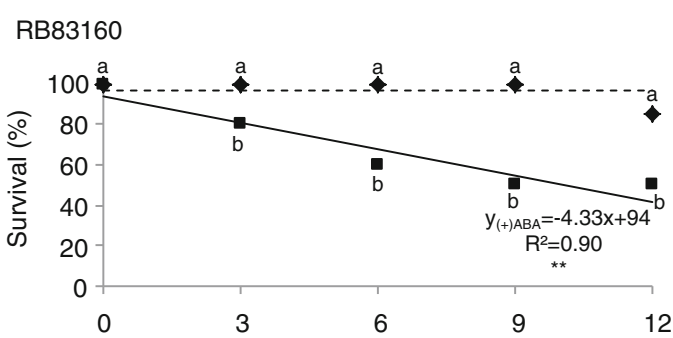

RB863129
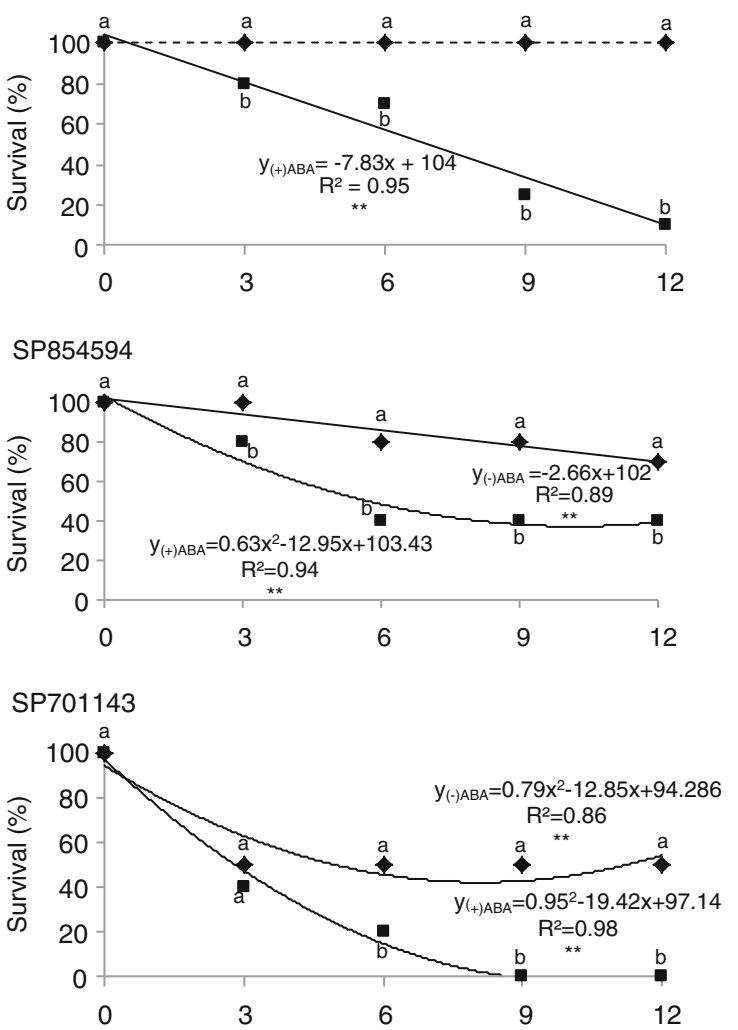

VAT90-212

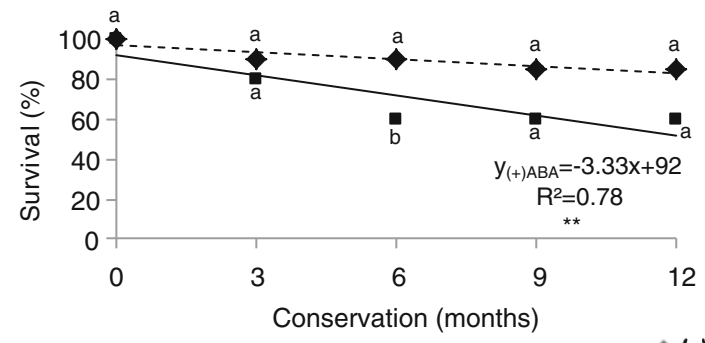

$\bullet$ (-) ABA

Figure 1 Behavior of Brazilian sugarcane varieties during 12 mo storage in vitro, in medium with or without $3.8 \mu \mathrm{M} \mathrm{ABA}$. *Means followed by the same letter within each month of evaluation belong to the same group

periods can result in nutrient depletion that may affect their long-term survival (Ahmed and Anjum 2010). To conserve Pyrus sp., the reduction of salts in the medium provided the best survival and regeneration rates for $6 \mathrm{mo}$, but after that time, death of shoots was observed probably due to depleted
RB845210

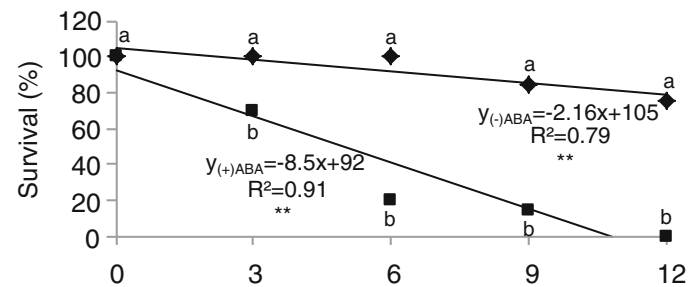

RB99395

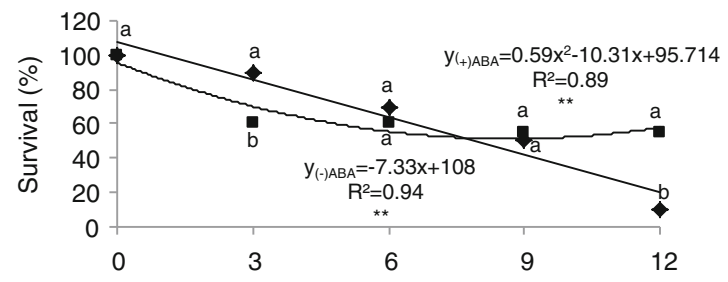

VAT90-186

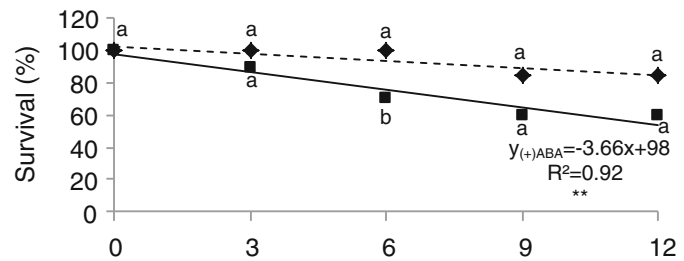

SP716949

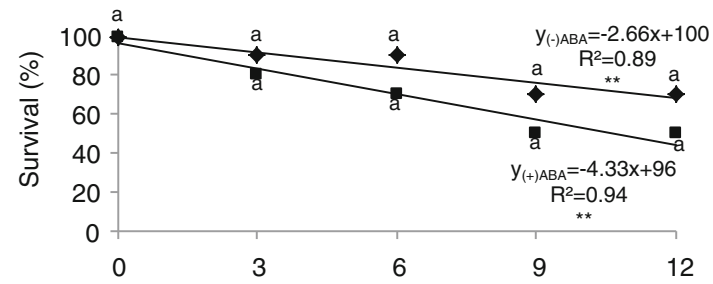

SP784764

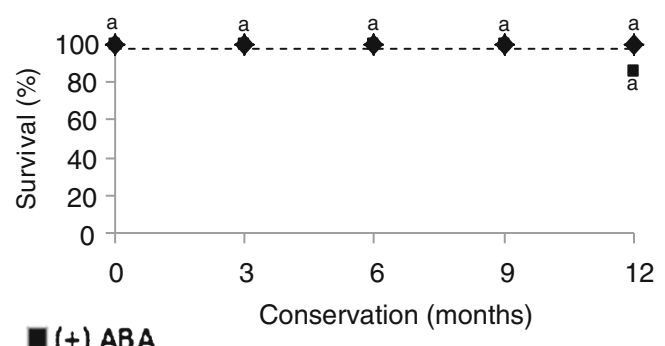

and do not present significant differences between treatments by the Scott-Knott test $(P>.05)$. **Significant by the regression test.

nutrient availability (Ahmed and Anjum 2010). For Lata et al. (2010), the combination of several factors, including contamination, desiccation, and reduction of nutrients in the culture medium, was detrimental to the survival of Podophyllum peltatum during storage. 
Table 2 Length of shoots, number of roots and secondary shoots $(\mathrm{sec})$ formed in sugarcane varieties during in vitro storage in culture medium supplemented or not with abscisic acid at a concentration of $3.8 \mu \mathrm{M}$.

\begin{tabular}{|c|c|c|c|c|c|c|}
\hline \multirow[b]{2}{*}{ Variety } & \multicolumn{2}{|l|}{ Length (cm) } & \multicolumn{2}{|l|}{ Number of roots } & \multicolumn{2}{|c|}{ Number of sec shoots } \\
\hline & $(-) \mathrm{ABA}$ & $(+) \mathrm{ABA}$ & $(-) \mathrm{ABA}$ & $(+) \mathrm{ABA}$ & $(-) \mathrm{ABA}$ & $(+) \mathrm{ABA}$ \\
\hline SP701143 & $1.8 \mathrm{cA}^{\mathrm{x}}$ & $-^{\mathrm{y}}$ & $3.4 \mathrm{bA}$ & - & $0.8 \mathrm{aA}$ & - \\
\hline RB99395 & $1.5 \mathrm{cA}$ & $1.6 \mathrm{aA}$ & $1.2 \mathrm{bA}$ & $3.1 \mathrm{aB}$ & $0.0 \mathrm{bA}$ & $0.1 \mathrm{aA}$ \\
\hline RB845210 & $3.7 \mathrm{aA}$ & - & $12.0 \mathrm{aA}$ & - & $0.1 \mathrm{bA}$ & - \\
\hline SP854594 & $2.5 \mathrm{bA}$ & $1.7 \mathrm{aA}$ & $6.8 \mathrm{bA}$ & $3.3 \mathrm{aA}$ & $1.2 \mathrm{aA}$ & $0.0 \mathrm{aB}$ \\
\hline VAT90-212 & $2.5 \mathrm{bA}$ & $1.6 \mathrm{aB}$ & $12.0 \mathrm{aA}$ & $3.9 \mathrm{aB}$ & $0.8 \mathrm{aA}$ & $0.6 \mathrm{aA}$ \\
\hline SP716949 & $2.7 \mathrm{bA}$ & $1.6 \mathrm{aB}$ & $8.9 \mathrm{aA}$ & $9.0 \mathrm{aA}$ & $0.7 \mathrm{aA}$ & $0.6 \mathrm{aA}$ \\
\hline RB863129 & $2.5 \mathrm{bA}$ & $1.5 \mathrm{aB}$ & $4.9 \mathrm{bA}$ & $2.8 \mathrm{aB}$ & $0.5 \mathrm{bA}$ & $0.0 \mathrm{aA}$ \\
\hline RB83160 & $2.8 \mathrm{bA}$ & $1.6 \mathrm{aB}$ & $3.3 \mathrm{bA}$ & $3.1 \mathrm{aA}$ & $0.3 \mathrm{bA}$ & $0.2 \mathrm{aA}$ \\
\hline VAT90-186 & $2.2 \mathrm{bA}$ & $1.5 \mathrm{aB}$ & $4.8 \mathrm{bA}$ & $3.1 \mathrm{aA}$ & $0.6 \mathrm{aA}$ & $0.1 \mathrm{aA}$ \\
\hline SP784764 & $3.4 \mathrm{aA}$ & $1.5 \mathrm{aB}$ & $7.9 \mathrm{bA}$ & $5.1 \mathrm{aA}$ & $0.2 \mathrm{bA}$ & $0.2 \mathrm{aA}$ \\
\hline
\end{tabular}

The culture medium consisted of $1 / 2$ MS basal medium with $3 \%$ sorbitol

Different uppercase letters within each variable differ among each other by the $F$ test

${ }^{\mathrm{x}}$ Means followed by the same lower case letter in a column belong to the same group and do not differ by the Scott-Knott test at $5 \%$ probability

${ }^{\mathrm{y}}$ Dead shoots

In this work, despite the yellowing of older leaves throughout the conservation period in $\mathrm{MC1}$, physiological damage to the explants and/or decrease in viability were not observed, a

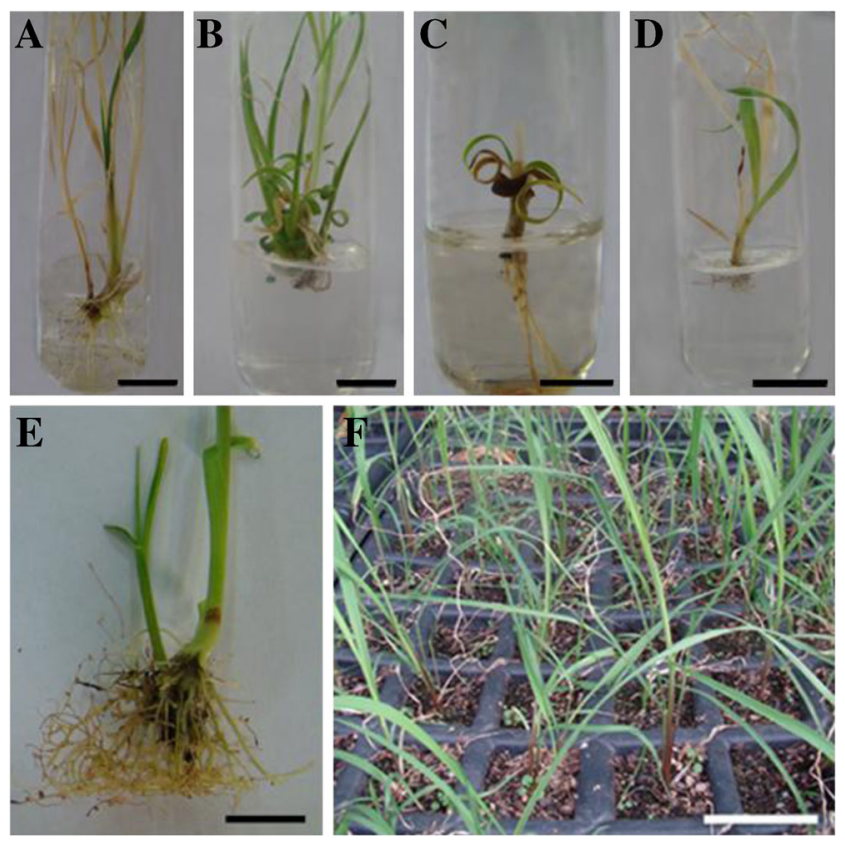

Figure 2 Growth recovery, rooting and acclimatization of sugarcane shoots after 12 mo of in vitro conservation. (A) Shoots kept in $1 / 2 \mathrm{MS}$ with 3\% sorbitol (MC1). (B) Growth recovery of shoots from MC1 after $30 \mathrm{~d}$ in multiplication medium. (C) Shoot kept in $1 / 2$ MS with $3 \%$ and $3.8 \mu \mathrm{M}$ ABA (MC2) after 12 mo of in vitro conservation. $(D)$ Growth recovery of shoots from $\mathrm{MC} 2$ after $30 \mathrm{~d}$ in multiplication medium. $(E)$ In vitro rooted plants. $(F)$ Adaptation of plants to acclimatization $21 \mathrm{~d}$ after the transfer to greenhouse. Bars, $1.0 \mathrm{~cm}(A-E) ; 5.0 \mathrm{~cm}(F)$. fact confirmed by the majority growth recovery. After 1 yr of storage under minimal growth conditions, shoots transferred to multiplication medium recovered rapidly through the emission of new leaves, shoot growth, and production of new shoots. It is noteworthy that the shoots visually assessed as viable, recovered growth during this phase Fig. $2 A-D$. All 10 varieties stored on $\mathrm{MC1}$ responded well, and no significant differences were observed among them with respect to production of new shoots in two consecutive subcultures of $30 \mathrm{~d}$ each performed.

According to the results presented in Table 3, the proliferation of secondary shoots was significantly higher in the second subculture. These results demonstrated a need for physiological recovery of explants prior to the resumption of the multiplication potential. Similar results were found by Marino et al. (2010) in the conservation of Prunus armeniaca shoots. These authors found that the highest shoot proliferation occurred in the second consecutive subculture, and the treatment applied during the storage period also influenced these results. Silva et al. (2012) noted differences in recovery of Vitis vinifera genotypes in terms of number of shoots and buds in various subcultures analyzed.

The sugarcane genotypes influenced reactivation of sugarcane explant growth on MC2. With regard to the production of new shoots, we observed superiority of SP716949 compared with the other varieties, with an average of 4.8 and 10.0 shoots per explant in the first and second subcultures, respectively. The RB83160 variety showed a significant increase in the production of new shoots in the second subculture (Table 3). The other varieties showed a low secondary shoot production capacity after the conservation period. For both treatments, the 
Table 3 Growth recovery after one and two subcultures (Subc) in multiplication medium following 12 mo of in vitro conservation in the presence or absence of $3.8 \mu \mathrm{M}$ ABA.

\begin{tabular}{|c|c|c|c|c|c|c|c|c|}
\hline \multirow[t]{3}{*}{ Variety } & \multicolumn{4}{|c|}{$\mathrm{N}$ of shoots } & \multicolumn{4}{|c|}{ Length $(\mathrm{cm})$} \\
\hline & \multicolumn{2}{|c|}{$(-) \mathrm{ABA}$} & \multicolumn{2}{|c|}{$(+) \mathrm{ABA}$} & \multicolumn{2}{|c|}{$(-) \mathrm{ABA}$} & \multicolumn{2}{|c|}{$(+) \mathrm{ABA}$} \\
\hline & Sub. 1 & Subc. 2 & Subc. 1 & Subc. 2 & Subc. 1 & Subc. 2 & Subc. 1 & Subc. 2 \\
\hline SP701143 & $1.5 \mathrm{aB}^{\mathrm{x}}$ & $9.0 \mathrm{aA}$ & $-{ }^{\mathrm{y}}$ & - & $3.5 \mathrm{aA}$ & $2.9 \mathrm{aA}$ & - & - \\
\hline RB99395 & - & - & $1.5 \mathrm{bB}$ & $12.0 \mathrm{aA}$ & - & - & $2.0 \mathrm{aB}$ & $3.0 \mathrm{aA}$ \\
\hline RB845210 & $1.5 \mathrm{aB}$ & $6.8 \mathrm{aA}$ & - & - & $2.7 \mathrm{aB}$ & $3.7 \mathrm{aA}$ & - & - \\
\hline SP854594 & $0.8 \mathrm{aA}$ & $3.0 \mathrm{aA}$ & $0.0 \mathrm{bA}$ & $1.0 \mathrm{bA}$ & $2.2 \mathrm{aA}$ & $2.0 \mathrm{bA}$ & $1.9 \mathrm{aB}$ & $3.0 \mathrm{aA}$ \\
\hline VAT90-212 & $1.7 \mathrm{aB}$ & $7.0 \mathrm{aA}$ & $0.4 \mathrm{bA}$ & $10.0 \mathrm{aA}$ & $3.1 \mathrm{aA}$ & $3.3 \mathrm{aA}$ & $2.0 \mathrm{aA}$ & $1.9 \mathrm{bA}$ \\
\hline SP716949 & $2.0 \mathrm{aB}$ & $9.6 \mathrm{aA}$ & $4.8 \mathrm{aB}$ & - & $2.7 \mathrm{aB}$ & $3.4 \mathrm{aA}$ & $2.6 \mathrm{aB}$ & $3.4 \mathrm{aA}$ \\
\hline RB863129 & $1.7 \mathrm{aB}$ & $7.5 \mathrm{aA}$ & - & $1.0 \mathrm{bA}$ & $2.2 \mathrm{aB}$ & $3.6 \mathrm{aA}$ & - & - \\
\hline RB83160 & $0.3 \mathrm{aB}$ & $5.2 \mathrm{aA}$ & $0.0 \mathrm{bA}$ & $3.2 \mathrm{bA}$ & $2.1 \mathrm{aB}$ & $3.6 \mathrm{aA}$ & $1.7 \mathrm{aA}$ & $2.0 \mathrm{bA}$ \\
\hline VAT90-186 & $1.7 \mathrm{aB}$ & $8.4 \mathrm{aA}$ & $0.5 \mathrm{bA}$ & $3.0 \mathrm{bA}$ & $2.6 \mathrm{aB}$ & $3.4 \mathrm{aA}$ & $2.1 \mathrm{aB}$ & $3.2 \mathrm{aA}$ \\
\hline SP784764 & $1.6 \mathrm{aB}$ & $4.4 \mathrm{aA}$ & $0.7 \mathrm{bA}$ & & $2.6 \mathrm{aB}$ & $3.2 \mathrm{aA}$ & $2.2 \mathrm{aB}$ & $3.6 \mathrm{aA}$ \\
\hline
\end{tabular}

The multiplication medium consisted of MS basal medium with $3 \%$ sucrose, $0.47 \mu \mathrm{M}$ Kin, and $0.9 \mu \mathrm{M}$ BAP

${ }^{\mathrm{x}}$ Means followed by the same lowercase letters in a column do not differ statistically from each other and belong to the same group by the Scott-Knott test at 5\% probability. Different capital letters within each variable differ by the $F$ test

${ }^{\mathrm{y}}$ Dead shoots

shoot length, in general, was higher in the second subculture and did not differ significantly among varieties.

For sugarcane that shows rapid growth and accelerated consumption of available nutrients in the culture medium, this work represents a breakthrough for maintaining germplasm under aseptic and controlled conditions. We observed a rapid growth recovery, and the multiplication potential was maintained even after the storage period. However, Liu et al. (2004) stated that the goal of plant genetic resource conservation covers not only the storage of germplasm but also the maintenance of low levels of variations of the material during this period. For these authors, any conservation method can be used provided that genetic material remains genetically stable.

Genomic stability analysis by flow cytometry. The amount of DNA determined by flow cytometry was calculated for the initial (control), intermediate (6 mo), and final period (12 mo) of in vitro storage for the 10 sugarcane varieties. In general, the analysis of the young inner leaves of the shoots produced in vitro resulted in a G1 DNA peak with coefficients of variation under $3 \%$, i.e., within the acceptable range of $5 \%$ as a routine value (Marie and Brown; 1993; Dolezel and Bartos 2005; Fig. 3). From the histogram analysis, we noted that despite the idea that sugarcane plants have generally tolerated the conservation conditions and remained morphologically normal throughout the experiment, they showed genomic instability at $12 \mathrm{mo}$ of in vitro storage.

In Table 4, a significant reduction in DNA content was verified in the relative amount of DNA estimated at 12 mo of in vitro storage for most of the varieties analyzed, except for
VAT90-212 where the reduction was already observed after 6 mo of storage. Initially in the conservation experiment, the estimated DNA content ranged between 12.2 and $12.8 \mathrm{pg}$. After storage by minimal growth, induced by modifications in the composition of the culture medium and the physical environment, the values were less than $12.05 \mathrm{pg}$, alternating between higher and lower values among varieties. The SP784764 variety was the only one that did not differ statistically regarding the relative amount of DNA of the shoots for the three analyses (Table 4). With respect to the source medium, we observed a reduction in the amount of DNA in plants stored in the presence of ABA (MC1) as well as in its absence (MC2; data not shown).

The relative size of the sugarcane genome is related to the number of chromosomes (Zhang et al. 2012). As this species presents one of the most complex genomes in the plant kingdom, we can assume that the stress conditions caused by the in vitro environment may have lead to the occurrence of chromosome breakage and/or missing chromosomes, a result of the prolonged storage period or in response to environmental conditions (Deumling and Clermont 1989; Bairu et al. 2011). Endemann et al. (2001) suggested that a prolonged time in culture could result in heterogeneous levels of nuclear DNA in regenerated plants. Similarly, Jin et al. (2008) observed a decrease in the relative amount of DNA in Gossypium hirsutum plants regenerated in vitro. According to these authors, the chromosome counts confirmed the results observed by flow cytometry and demonstrated the occurrence of aneuploid plants with losses of 4 or 5 chromosomes. Some authors believe that the late replication of heterochromatin in 

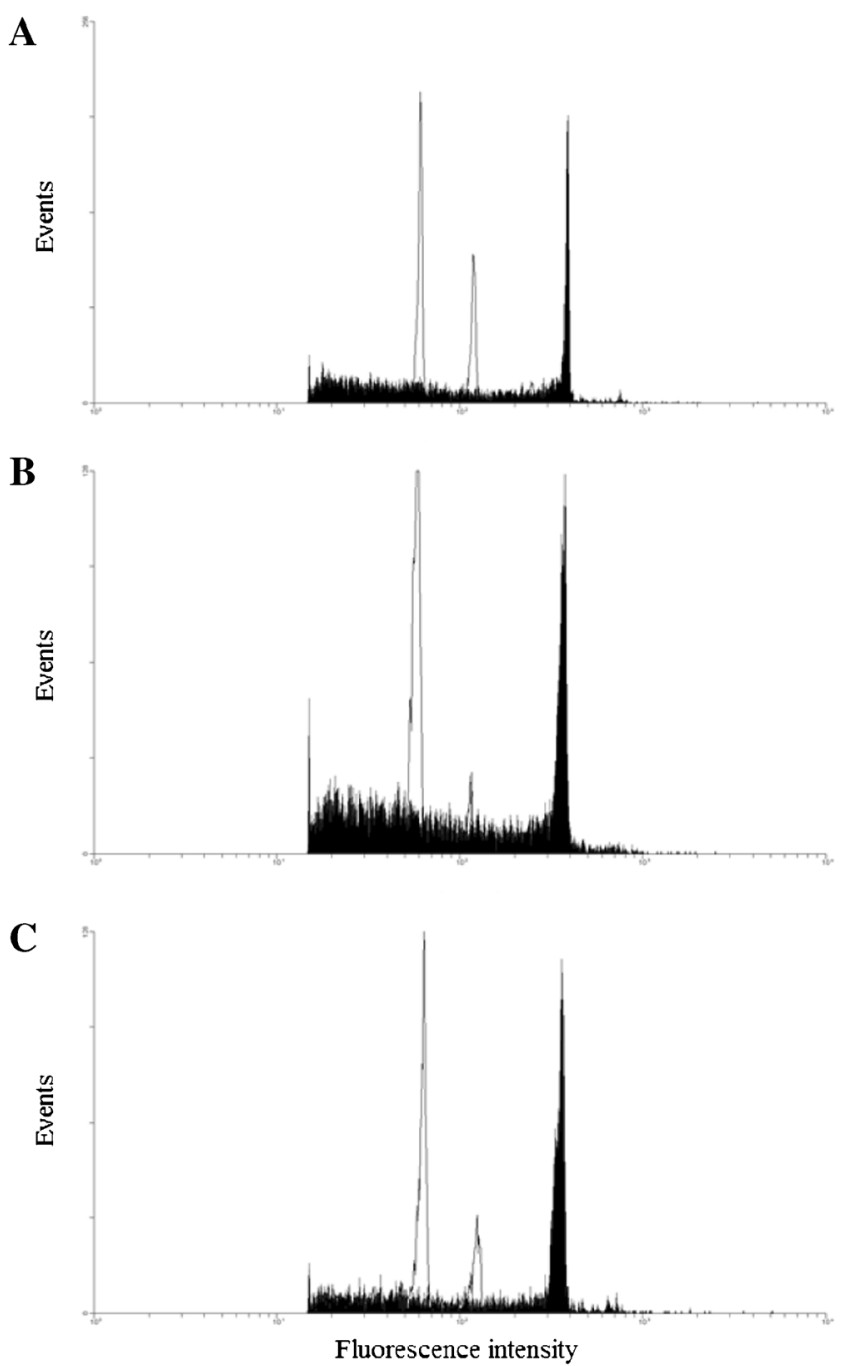

Figure 3 Histograms showing flow cytometry analysis of the amount of DNA in the sugarcane plants obtained using Marie buffer. The first and second peaks correspond to the tomato plant standard (peaks at $\mathrm{G}_{0} / \mathrm{G}_{1}$ and $\mathrm{G}_{2}$ phases), and the third peak corresponds to the variety SP854594. (A) Control treatment. (B) At 6 mo of in vitro conservation. (C) At 12 mo of in vitro conservation.

response to in vitro conditions and/or variations in the levels of DNA methylation can lead to the formation of bridges, chromosomal breaks, or rearrangements (Kaeppler et al. 2000; Endemann et al. 2001).
Rooting and acclimatization. After in vitro storage for a period of 12 mo and the resumption of growth, the sugarcane plants formed adventitious roots in culture medium devoid of growth regulators and thus allowed transfer of regenerated plantlets to the greenhouse. Under ex vitro conditions, the plant survival percentage was higher than $90 \%$, regardless of treatment source (MC1 and MC2). The sugarcane plants adapted efficiently to the new culture conditions, which were verified from the shoot growth and density of the root system Fig. 2E-F. In general, we noted that in spite of the variation in the amount of DNA detected by flow cytometry, sugarcane plants acclimatized after $1 \mathrm{yr}$ of storage and presented as morphologically normal and healthy.

\section{Conclusions}

The combination of sorbitol and reduced growth temperature was efficient for survival of sugarcane varieties during in vitro storage by minimal growth. Under these conditions, the plants remained viable for a period of $12 \mathrm{mo}$, growth recovery was rapid, and shoot multiplication capacity also recovered during the second 30-d subculture. However, maintenance of genotypes in vitro for long cultivation periods led to genomic instability of the plants, detected by a reduction in the relative amount of nuclear DNA. Despite the reduction in the relative amount of DNA observed by flow cytometry analysis for most varieties examined, further studies and cytogenetic analyses should be performed on this material to detect and/or confirm any loss or chromosomes or other chromosomal abnormalities. Moreover, as the plants were morphologically normal, acclimatization in greenhouse and monitoring of their development in such an external environment is recommended. Through cytological studies, Sobhakumari (2012) detected variations in the number of chromosomes, as well as fragmented chromosomes, in sugarcane plants regenerated via somatic embryogenesis. However, in this case, phenotypic variations were also observed. Unlike these reports, numerous other species evaluated showed no variation in the relative DNA content in plants regenerated and propagated in vitro

Table 4 Average relative DNA content (pg) of Brazilian varieties of sugarcane during the in vitro conservation period in minimal growth culture medium.

\begin{tabular}{|c|c|c|c|c|c|c|c|c|c|c|}
\hline \multirow[t]{2}{*}{ Conservation period } & \multicolumn{10}{|l|}{ Variety } \\
\hline & RB83160 & VAT90186 & VAT90212 & RB99395 & SP701143 & RB863129 & SP854594 & SP784764 & RB845210 & SP716949 \\
\hline Control & $12.67 \mathrm{a}^{\mathrm{x}}$ & $12.45 \mathrm{a}$ & $12.4 \mathrm{a}$ & $12.30 \mathrm{a}$ & $12.53 \mathrm{a}$ & $12.26 \mathrm{a}$ & $12.37 \mathrm{a}$ & $12.18 \mathrm{a}$ & $12.87 \mathrm{a}$ & $12.81 \mathrm{a}$ \\
\hline $6 \mathrm{mo}$ & $12.46 \mathrm{a}$ & $12.41 \mathrm{~b}$ & $11.81 \mathrm{~b}$ & $12.11 \mathrm{ab}$ & $12.47 \mathrm{a}$ & $12.21 \mathrm{a}$ & $12.34 \mathrm{a}$ & $12.39 \mathrm{a}$ & $12.86 \mathrm{a}$ & $12.82 \mathrm{a}$ \\
\hline $12 \mathrm{mo}$ & $11.85 \mathrm{~b}$ & $12.05 \mathrm{~b}$ & $11.90 \mathrm{~b}$ & $11.83 \mathrm{~b}$ & $11.66 \mathrm{~b}$ & $11.42 \mathrm{~b}$ & $11.50 \mathrm{~b}$ & $12.28 \mathrm{a}$ & $11.91 \mathrm{~b}$ & $12.01 \mathrm{~b}$ \\
\hline
\end{tabular}

${ }^{\mathrm{x}}$ Means followed by the same letter belong to the same group by the Tukey test at $5 \%$ probability 
(Brito et al. 2010; Silva et al. 2011; Ochatt et al. 2013), which ensures the efficiency of tissue culture techniques for the production of genetically stable and uniform plants. However, reports of genomic integrity by flow cytometry in plants maintained in vitro are scarce and have previously been nonexistent for sugarcane.

Acknowledgment The authors thank the National Council for Scientific and Technological Development $(\mathrm{CNPq} / \mathrm{Brazil})$ and Financier of Studies and Projects (Finep/Brazil) for the fellowship, research grants, and financial support.

\section{References}

Ahmed M, Anjum MA (2010) In vitro storage of some pear genotypes with the minimal growth technique. Turk J Agric For 34:25-32

Bairu MW, Aremu AO, Van Staden J (2011) Somaclonal variation in plants: causes and detection methods. Plant Growth Regul 63:147-173

Brito G, Lopes T, Loureiro J, Rodriguez E, Santos C (2010) Assessment of genetic stability of two micropropagated wild olive species using flow cytometry and microsatellite markers. Trees 24:723-732

Cheng JJ, Timilsina GR (2011) Status and barriers of advanced biofuel technologies: a review. Renew Energy 36:3541-3549

Cid LPB, Carvalho L (2008) Importance of abscisic acid (ABA) in the in vitro conservation of cassava (Manihot esculenta Crantz). Chil $\mathrm{J}$ Agric Res 68:304-308

Clarindo WR, Carvalho CR, Mendonça MAC (2012) Ploidy instability in long-term in vitro cultures of Coffea arabica L. monitored by flow cytometry. Plant Growth Regul 68:533-538

Comai L (2005) The advantages and disadvantages of being polyploid. Nat Rev Genet 6:836-846

Danso KE, Ford-Llyod BV (2008) The effect of abscisic acid and sucrose on post-thaw embryogenic competence and subsequent plant recovery from embryogenic calli of cassava. Am Eurasian J Agri Environ Sci 3:663-671

Deumling B, Clermont L (1989) Changes in DNA content and chromosomal size during cell culture and plant regeneration of Scilla siberica: selective chromatin diminution in response to environmental conditions. Chromosoma 97:439-448

Dolezel J, Bartos J (2005) Plant DNA flow cytometry and estimation of nuclear genome size. Ann Bot 95:99-110

Dolezel J, Dolezelova M, Novak FJ (1994) Flow cytometric estimation of nuclear-DNA amount in diploid bananas (Musa acuminata and M. balbisiana). Biol Plant 36:351-357

Dos Santos JM, Duarte Filho LSC, Soriano ML, da Silva PP, Nascimento VX, de Souza Barbosa GV, Todaro AR, Ramalho Neto CE, Almeida C (2012) Genetic diversity of the main progenitors of sugarcane from the RIDESA germplasm bank using SSR markers. Ind Crop Prod 40:145-150

Edmé SJ, Comstock JC, Miller JD, Tai PYP (2005) Determination of DNA content and genome size in sugarcane. J Amer Soc Sugar Cane Technol 25:1-16

Endemann M, Hristoforoglu K, Stauber T, Wilhelm E (2001) Assessment of age-related polyploidy in Quercus robur L. somatic embryos and regenerated plants using DNA flow cytometry. Biol Plant 44:339-345

Engelmann F (2011) Use of biotechnologies for the conservation of plant biodiversity. Vitro Cell Dev Biol-Plant 47:5-16

Escobedo-GraciaMedrano RM, Maldonado-Borges JI, Burgos-Tan MJ, Valadez-González N, Ku-Cauich JR (2014) Using flow cytometry and cytological analyses to assess the genetic stability of somatic embryo-derived plantlets from embryogenic Musa acuminata Colla
(AA) ssp. malaccensis cell suspension cultures. Plant Cell Tissue Organ Cult 116:175-185

Ferreira DF (2011) Sisvar: a computer statistical analysis system. Ciênc Agrotec 35:1039-1042

Garcia AAF, Mollinari M, Marconi TG, Serang OR, Silva RR, Vieira MLC, Vicentini R, Costa EA, Mancini MC, Garcia MOS, Pastina MM, Gazaffi R, Martins ERF, Dahmer N, Sforça DA, Silva CBC, Bundock P, Henry RJ, Souza GM, van Sluys MA, Landell MGA, Carneiro MS, Vincentz MAG, Pinto LR, Vencovsky R, Souza AP (2013) SNP genotyping allows an in-depth characterisation of the genome of sugarcane and other complex autopolyploids. Sci Rep 3:3399

Gill R, Malhotra PK, Gosal SS (2006) Direct plant regeneration from cultured young leaf segments of sugarcane. Plant Cell Tissue Organ Cult 84:227-231

Gopal J, Chamail A, Sarkar D (2004) In vitro production of microtubers for conservation of potato germplasm: effect of genotype, abscisic acid, and sucrose. Vitro Cell Dev Biol Plant 40:485-490

Huang WJ, Ning GG, Liu GF, Bao MZ (2009) Determination of genetic stability of long-term micropropagated plantlets of Platanus acerifolia using ISSR markers. Biol Plant 53:159-163

Jin S, Mushke R, Zhu H, Tu L, Lin Z, Zhang Y, Zhang X (2008) Detection of somaclonal variation of cotton (Gossypium hirsutum) using cytogenetics, flow cytometry and molecular markers. Plant Cell Rep 27:1303-1316

Kaeppler SM, Kaeppler HF, Rhee Y (2000) Epigenetic aspects of somaclonal variation in plants. Plant Mol Biol 43:179-188

Lata H, Moraes RM, Bertoni B, Pereira AMS (2010) In vitro germplasm conservation of Podophyllum peltatum L. under slow growth conditions. Vitro Cell Dev Biol Plant 46:22-27

Lemos EEP, Ferreira MS, De Alencar LMC, Ramalho Neto CE, De Albuquerque MM (2002) In vitro conservation of sugarcane germplasm. Pesq Agrop Brasileira 37:1359-1364

Liu YG, Wang XY, Liu LX (2004) Analysis of genetic variation in surviving apple shoots following cryopreservation by vitrification. Plant Sci 166:677-685

Madon M, Heslop-Harrison JS, Schwarzacher T, Hashim AT (2012) Analysis of oil palm calli and regenerants using flow and image cytometry and 18S-25S ribosomal DNA fluorescence in situ hybridisation (FISH). J Oil Palm Res 24:1318-1329

Marie D, Brown SCA (1993) Cytometric exercise in plant DNA histograms, with 2C-values for 70 species. Biol Cell 78:41-51

Marino G, Negri P, Cellini A, Masia A (2010) Effect of carbohydrates on in vitro low-temperature storage of shoot cultures of apricot. Sci Hortic 126:434-440

Martín C, Senula A, González I, Acosta A, Keller ERJ, González-Benito ME (2013) Genetic identity of three mint accessions stored by different conservation procedures: field collection, in vitro and cryopreservation. Genet Resour Crop Evol 60:243-249

Matsuoka S, Ferro J, Arruda P (2009) The Brazilian experience of sugarcane ethanol industry. Vitro Cell Dev Biol Plant 45:372-381

Msogoya TJ, Grout BW, Roberts A (2011) Reduction in genome size and DNA methylation alters plant and fruit development in tissue culture induced off-type banana (Musa spp.). J Anim Plant Sci 11: $1450-1456$

Murashige T, Skoog F (1962) A revised medium for rapid growth and bioassays with tobacco tissue cultures. Physiol Plant 15:473-497

Naidu MM, Sreenath HL (1999) In vitro culture of coffee zygotic embryos for germplasm preservation. Plant Cell Tissue Organ Cult 55:227-230

Neelakandan AK, Wang K (2012) Recent progress in the understanding of tissue culture-induced genome level changes in plants and potential applications. Plant Cell Rep 31:597-620

Nogueira GF, Pasqual M, Scherwinski-Pereira JE (2013) Survival of sugarcane shoot tips after cryopreservation by droplet-vitrification. Pesq Agrop Brasileira 48:1524-1527

Ochatt SJ, Conreux C, Jacas L (2013) Flow cytometry distinction between species and between landraces within Lathyrus species and 
assessment of true-to-typeness of in vitro regenerants. Plant Syst Evol 299:75-85

Park JW, Solis-Gracia N, Trevino C, da Silva JA (2012) Exploitation of conserved intron scanning as a tool for molecular marker development in the Saccharum complex. Mol Breeding 30:987-999

Popova EV, Lee EJ, Wu CH, Hahn EJ, Paek KY (2009) A simple method for cryopreservation of Ginkgo biloba callus. Plant Cell Tissue Organ Cult 97:337-343

Prado MJ, Rodriguez E, Rey L, González MV, Santos C, Rey M (2010) Detection of somaclonal variants in somatic embryogenesis regenerated plants of Vitis vinifera by flow cytometry and microsatellite markers. Plant Cell Tissue Organ Cult 103: $49-59$

Rai MK, Shekhawat NS, Harish GAK, Phulwaria M, Ram K, Jaiswal U (2011) The role of abscisic acid in plant tissue culture: a review of recent progress. Plant Cell Tissue Organ Cult 106:179-190

Roach BT (1995) Case for a core collection of sugarcane germplasm. Proc Int Soc Sugar Cane Technol 21:339-350

Sainz MB (2009) Commercial cellulosic ethanol: the role of plantexpressed enzymes. Vitro Cell Dev Biol Plant 45:314-329

Sarwar M, Siddiqui SU (2004) In vitro conservation of sugarcane (Saccharum officinarum L.) germplasm. Pak J Bot 36:549-556

Scherwinski-Pereira JE, Costa FHS (2010) Conservação in vitro de recursos genéticos de plantas: estratégias, princípios e aplicações. In: Barrueto Cid LP (ed) Cultivo in vitro de plantas. Embrapa Informação Tecnológica, Brasília, pp 177 234, in Portuguese

Silva TL, Scherwinski-Pereira JE (2011) In vitro conservation of Piper aduncum and Piper hispidinervum under slow-growth conditions. Pesq Agrop Brasileira 46:384-389

Silva CV, De Oliveira LS, Loriato VAP, Da Silva LC, De Campos JMS, Viccini LF, DE Oliveira EJ, Otoni WC (2011) Organogenesis from root explants of commercial populations of Passiflora edulis Sims and a wild passion fruit species, $P$. cincinnata Masters. Plant Cell Tissue Organ Cult 107:407-416
Silva RC, Luis ZG, Scherwinski-Pereira JE (2012) Differential responses to somatic embryogenesis of different genotypes of Brazilian oil palm (Elaeis guineensis Jacq.). Plant Cell Tissue Organ Cult 111: $59-67$

Singh SR, Dalal S, Singh R, Dhawan AK, Kalia RK (2013) Ascertaining clonal fidelity of micropropagated plants of Dendrocalamus hamiltonii Nees et Arn. ex Munro using molecular markers. Vitro Cell Dev Biol Plant 49:572-583

Smulders MJM, de Klerk GJ (2011) Epigenetics in plant tissue culture. Plant Growth Regul 63:137-146

Sobhakumari VP (2012) Assessment of somaclonal variation in sugarcane. Afr J Biotechnol 11:15303-15309

Suganya A, Nithiyanantham R, Premachandran MN, Balasundaram N, Govindaraj P, Selvi A, Nair NV (2012) Cytological studies in hybrids between a sugarcane cultivar and three cytotypes of wild Saccharum spontaneum L. J Sugarcane Res 2:34-40

Taylor PWJ, Dukic S (1993) Development of an in vitro culture technique for conservation of Saccharum spp. hybrid germplasm. Plant Cell Tissue Organ Cult 34:217-222

Vujović T, Cerović R, Ružić D (2012) Ploidy level stability of adventitious shoots of sour cherry 'Cacanski Rubin' and Gisela 5 cherry rootstock. Plant Cell Tissue Organ Cult 111:323-333

Waclawovsky AJ, Sato PM, Lembke CG, Moore PH, Souza GM (2010) Sugarcane for bioenergy production: an assessment of yield and regulation of sucrose content. Plant Biotechnol J 8:263-276

Watt MP, Thokoane NL, Mycock D, Blakeway F (2000) In vitro storage of Eucalyptus grandis germplasm under minimal growth conditions. Plant Cell Tissue Organ Cult 61:161-164

Yang XM, An LZ, Xiong YC, Zhang JP, Li Y, Xu SJ (2008) Somatic embryogenesis from immature zygotic embryos and monitoring the genetic fidelity of regenerated plants in grapevine. Biol Plant 52: 209-214

Zhang J, Nagai C, Yu Q, Pan YB, Ayala-Silva T, Schnell RJ, Comstock JC, Arumuganathan AK, Ming R (2012) Genome size variation in three Saccharum species. Euphytica 185:511-519 